emeritus professor of mining geology, University of London (Imperial College of Science and Technology), for services to the Board of Trade; C. Kershaw, director of British Optical and Precision Engineers, Ltd., for services to the production of optical instruments; Dr. A. King, chief scientific liaison officer, Office of the Lord President of the Council; Prof. H. A. D. Neville, lately professor of agricultural chemistry, University of Reading ; Miss Margery Perham, reader in Colonial administration, University of Oxford ; Prof. J. Ritchie, professor of natural history, University of Edinburgh; Dr. H. V. Taylor, lately senior education and advisory officer, Ministry of Agriculture; S. G. Taylor, director of irrigation, Ceylon.

\section{Sir James Chadwick, F.R.S.}

SIR JAMEs Chadwick has been pre-elected Master of Gonville and Caius College, Cambridge, of which he has been a fellow and more lately an honorary fellow. Sir James began his scientific work under Rutherford in Manchester; after studying in the University of Berlin he was interned in Germany during the First World War, and there continued his scientific researches. When Rutherford moved to Manchester, Chadwick joined him and took part in Rutherford's classical researches on the disintegration of elements by $\alpha$-particles. With Bieler and later with Rutherford he studied the scattering of $\alpha$-particles by hydrogen and heavier nuclei, and from these experiments determined the law of force around atomic nuclei. $\mathrm{He}$ became assistant director of research under Rutherford at Cambridge, and as such was responsible for the training of Rutherford's young research students and for the satisfaction of their modest needs. Many nuclear physicists will remember the attic of the Cavendish equipped with ancient vacuum pumps, gold-leaf electroscopes and the simple apparatus for counting $\alpha$-particles which was then the main tool of nuclear research. The discovery of the neutron in 1932, followed by the photodisintegration of the deuteron (with Goldhaber) and the creation of electron pairs by $\gamma$-rays (with Blackett and Occhialini), marked the peak of Chadwick's experimental work. In 1935 he was appointed Lyon Jones professor of physics in the University of Liverpool, and at once embarked on the construction of a 36-in. cyclotron, completing this just prior to the Second World War.

On the outbreak of war, Chadwick took up the study of nuclear chain reactions based on the fission of uranium, and with Frisch and Peierls informed the Government in the spring of 1940 that an atomic bomb could probably be produced if sufficient U235 were concentrated. Further studies of nuclear constants in Liverpool and Cambridge confirmed this view. At the end of 1943, Chadwick was largely instrumental in restoring the collaboration with the United States in atomic energy which was severed in 1941. He recruited a small but powerful British team to work in Los Alamos and Berkeley, and took a leading part with Dr. Mackenzie in establish. ing the Canadian Atomic Energy Project at Chalk River. Since the War he has served on the Scientific and Technical Committee of the United Nations Atomic Energy Commission. On his return to Liverpool he initiated the construction of a cyclotron to produce $300 \mathrm{MeV}$. protons. Chadwick's pupils in nuclear physics are distributed over the whole world. They will regret his severance from active experimental work but will all wish him well in the tasks which lie ahead.

\section{Dr. E. D. Merrill}

Dr. E. D. Merrill retires from the Arnold professorship of botany, Harvard University, at the end of June. As professor emeritus he is to remain in the house on the margin of the Arnold Arboretum that has been his as director of the Arboretum where, granted good health such as all his many friends wish him, he will enjoy the facilities for botanical study that have been so considerably shaped by him. Under him the inflow of material, living and dried, into the Garden and Herbarium from eastern Asia, Malaysia and the Pacific has been tremendous; and it is well that he should take a large part in elaborating it. Born on October 15, 1876, Elmer Drew Merrill passed in 1899 from College into the United States Department of Agriculture. In the Department he was selected (1902) for the appointment of government botanist in the Philippine Islands and went out to Manila, one of a few men chosen to start a science service towards which at that time there was nothing but a budgetary appropriation. It was soon evident that his methods were direct and effective. Botanical teaching was added (1912) to his work, and in 1918 the administration of the Bureau of Science. In 1923 the University of California sought and secured his service as dean of the College of Agriculture, where it was his duty to draw into order State-wide organisations that were growing up too loosely knit. In 1930 New York induced him to cross the continent to take the post of director-in-chief of the New York Botanic Garden. Institutions in the United States such as it, depend much on private generosity, and in bad times suffer checks to their activities: it is so in New York, and he had the years of the great depression to combat. It need be no secret that his successes in adjustment led to an invitation to move to Boston (1935) into a post made for him with the title of administrator of the Botanical Collections of the Harvard University and director of the Arnold Arboretum. The collections that passed under him had some likeness to the miscellany he set in order in California, at least in diversity. The University has rearranged these responsibilities; and his last, the teaching of advanced students in methods of research, passes elsewhere. He is now free to devote his time to botanical research.

\section{Dr. L. H. Bailey}

DR. LiBERTY HyDE BAILEy, eminent administrator, botanist, horticulturist and author, attained his ninetieth birthday on March 15. On this date he was actually on Arruba Island in the West Indies on one of his annual palm-hunting expeditions to tropical America. He was signally honoured on his return to Ithaca, New York, in May by a complimentary dinner sponsored by Cornell University, with which institution he has been associated for the past sixty years. On this occasion, with approximately two hundred guests in attendance from various parts of the United States, the speakers extolled Dr. Bailey's eminent services to Cornell University, to agricultural instruction, research and extension, to botany, to horticulture, and to the humanities. The outstanding feature of the evening was Dr. Bailey's informal address, which dealt with his early experiences and some of his later achievements. Tall, straight, speaking extemporaneously and without notes, it was indeed an inspiration to all who heard him on this occasion. 
Bailey's career has been an extraordinary one. His father was an early settler in what a century ago was the wilderness of Michigan, and the son's early years were thus associated with the primitive con. ditions of pioneer life. Following his graduation from college in 1882 he served for several years as assistant to the eminent American botanist Asa Gray at Harvard University, and it was this experience, plus his personal interests, which determined his future career. $\mathrm{He}_{\Theta}$ is the last living associate of Gray, who, in turn, was a frequent visitor to London and was the outstanding American exponent of the Darwinian hypothesis. Even when because of his special qualifications Bailey was selected as dean and director of agriculture at Cornell University in 1903, he accepted appointment only on the condition that he would be permitted to resign from administrative work at the end of ten years. $\mathrm{He}$ retired from academic work as emeritus professor of agriculture in 1921, but this did not mean quiescence on his part. His energies have since that date been devoted to his special botanical and horticultural interests, including the botany of cultivated beauty, an intensive study of North American Rubus, and a long-continued investigation of the palms and their classification; and it is this special interest in palms that has inspired him to make trip after trip to remote parts of Mexico, the West Indies and South America in recent years, with future ones already planned. In 1937 he presented his home, his library and his large herbarium to Cornell University, this unit being designated as "The Bailey Hortorium" ; and of this he is still the director. His honours have been very numerous, for the value of his achievements has been recognized all over the world. Among these is foreign membership of the Linnean Society and honorary membership of the Royal Horticultural Society of London.

\section{U.S. National Museum : Dr. A. Remington Kellogg}

Dr. A. Remingron Kelloga has been appointed director of the United States National Museum. Dr. Kellogg has been curator of mammals in the Smith. sonian Institution for the past seven years. $\mathrm{He}$ is one of the leading experts on whales and whale-like animals. His doctorate thesis, dealing with cetacean palæontology, attempted to trace the ancestry of the earth's largest animals from their land origins. He has served as delegate for the United States on several international congresses dealing with whale conservation and had a leading part in the establishment of the great Antarctic whale sanctuary set up by international agreement. The National Museum, which Dr. Kellogg now will administer, is the largest of the Federal bureaux administered by the Smith. sonian Institution. It is the storehouse of what now is probably the most extensive systematized natural history collections in the world, ranging from elephants to fossil insects. It contains large ethnological and historical collections and valuable series in the field of mechanies and inventions.

\section{University of Cambridge}

GENERAI SMUTS was installed as chancellor of the University of Cambridge on June 10. He then conferred honorary degrees on the following, among others : Mr. Winston Churchill ; Sir Stafford Cripps ; Sir Hector Hetherington, principal and vice-chancellor of the University of Glasgow; Mr. Charles Seymour, president of Yale University; Mr. J. F. Cameron, master of Gonville and Caius College, Cambridge;
Sir Hugh Lett, president of the British Medical Association; Sir Wilson Jameson, chief medical officer of the Ministries of Health and Education; Sir Richard Livingstone, vice-chancellor of the University of Oxford; Sir Robert Robinson, president of the Royal Society; Sir Paul Fildes, of the Medical Research Council ; and Mr. Arnold Toynbee, director of studies in the Royal Institute of International Affairs.

\section{National Federation of Educational Film Groups}

THE National Federation of Educational Film Groups recently held its first annual conference in King's College, University of London. Membership of the Federation now amounts to thirty-three groups, representing more than 2,500 teachers. The Federa. tion aims at co-ordinating and assisting the activities of groups of teachers specifically organised to encourage and develop the use of visual aids to teaching, at stimulating the formation and development of such groups, and at collating and analysing the views and knowledge of those experienced in visual methods. Its work includes the development of a library of film strips and charts, the publication of surveys of exist ing films under specific subject headings, and the organisation of courses for the study of visual aids. The main resolution debated at the conference welcomed the plans of the National Committee for Visual Aids and reaffirmed the support of the Federation in the Committee's task of promoting the wider adoption of visual methods in education. Attention was directed to the need for breaking the "vicious circle of supply and demand in materials", to the importance of reducing production costs, and to the necessity of ensuring that units making educational films were at all times assisted by clear directives. It was decided to establish a fact-finding committee which should report to the Council of the Federation on matters concerning the production and distribution of visual aids.

The conference was also made the occasion of an exhibition housed in the large hall of King's College and designed to provide a wide selection of equipment and materials for visual presentation. Makers, producers and distributors of visual material and projectors had been invited to exhibit and nearly fifty had accepted. The range of exhibits included film and film strip projectors, film strips, wall charts and accessories. An ingenious arrangement of stalls made for the convenience of both exhibitors and visitors and allowed demonstrations to proceed simultaneously. A useful guide-book was available containing details of exhibits and available sources of supply. A nearby room was used for full-length projection of educational films and film strips. The exhibition was well attended, and stall-holders were kept busy throughout the day. The idea of combining conference and exhibition was certainly a happy one, and the organisers are to be congratulated on this and on the excellence of their arrangements.

\section{Chemical Engineering and Fuel Technology at the University of Durham}

Commencrna in October 1948, King's College, Newcastle upon Tyne, will offer a two-year postgraduate course in chemical engineering leading to the degree of master of science in chemical engineering of the University of Durham. The course will be available to graduates in mechanical engineering or to those who possess some equivalent degree or qualification. The opportunity has been taken to 